\title{
Detection of Toxoplasma gondii in the milk of experimentally infected Wistar
} female rats

\section{Costa VM (1), Langoni H (1)}

(1) Zoonosis Research Center, NUPEZO, Veterinary Medicine and Animal Husbandry School, São Paulo State University (UNESP - Univ Estadual Paulista), Botucatu, São Paulo State, Brazil.

ABSTRACT: The milk of experimentally infected rats was investigated for the presence and possible transmission of Toxoplasma gondii. Wistar (Rattus norvegicus) female rats were divided into three groups and orally inoculated with bradyzoites. Polymerase chain reaction (PCR) was employed to detect the parasite in the milk. Transmission to the offspring was verified by indirect immunofluorescence antibody test (IFAT), modified agglutination test (MAT), bioassay tests and PCR. Rat milk samples were PCR-positive, pups were serumreactive to $T$. gondii and tissue samples also presented positive DNA results through PCR.

KEY WORDS: Toxoplasma gondii, parasite in milk, female rats, PCR, bioassay.

CONFLICTS OF INTEREST: There is no conflict.

FINANCIAL SOURCE: FAPESP and CNPq.

\section{CORRESPONDENCE TO:}

VERUSKA MAIA DA COSTA, Departamento de Higiene Veterinária e Saúde Pública, Faculdade de Medicina Veterinária e Zootecnia, UNESP, Distrito de Rubião Júnior, s/n, Botucatu, SP, 18.618-000, Brasil. Phone: 55143811 6270. Fax: 5514 3811 6075. Email: veruskamcosta@gmail.com. 


\section{INTRODUCTION}

Toxoplasmosis, a significant zoonosis, is caused by Toxoplasma gondii, whose transmission to humans can be due to consumption of infected milk (1-3). The milk of affected animals contains tachyzoites, which facilitates the transmission to the offspring (4). Riemann et al. (5) reported a case of T. gondii infection in children who probably contracted the disease by ingesting unpasteurized goat milk.

Among the studies on vertical transmission, only a few have reported the presence of tachyzoites in the milk of different species including sheep, goats, cattle and experimentally infected mice (6-8). Several aspects of the mechanisms responsible for toxoplasmic infection have been elucidated by using experimental models $(9,10)$. Rats are the animals most often employed in these works (11). Thus, the current study evaluated whether T. gondii was present in and transmitted through the milk of experimentally infected rats.

The experiment included 21 Wistar (Rattus norvegicus) rats, 18 were females and three were males used only in breeding. All were aged between 100 and 120 days and were seronegative for toxoplasmosis, which was confirmed before the beginning of the experiment by IFAT, according to Camargo (12), and by MAT, as described by Desmonts and Remington (13). In both assays, the titer 16 was considered positive. The experiment started only after the negative result had been obtained.

Females were divided into three groups: G1, G2 and G3. The G1 and G2 animals were inoculated by oral gavage with $10^{4}$ bradyzoites of the strain BTU4, named after the city, Botucatu, where it was isolated and classified as genotype I. G1 and G2 rats were observed for 60 days after inoculation. During this period, serological assays were carried out fortnightly by collecting blood samples from animals through retroorbital puncture with capillary tubes. Rats of the three groups mated and were daily observed until labor. At the $60^{\text {th }}$ day, G3 animals were infected as previously described and $\mathrm{G} 2$ rats were subjected to immunosuppression with dexamethasone (2.5 $\mathrm{mg} / \mathrm{kg} /$ day) for 15 days, following the protocol of Djurkovic-Djakovic and Milenkovic (14) adapted for the subcutaneous route.

To detect the parasite in the milk, samples were collected six times during the first 15 lactation days and submitted to PCR. Collections were carried out on alternate days until the $3^{\text {rd }}$ collection and every two days from the $4^{\text {th }}$ collection to the $15^{\text {th }}$ lactation day. To facilitate the collection of milky secretion, $1 \mathrm{~mL}$ (5 UI) of oxytocin was intraperitoneally injected into rats that were then milked through manual breast 
massage using a disposable sterile Pasteur pipette to aspirate approximately $300 \mu \mathrm{L}$ of milk (15).

T. gondii transmission to the offspring was evaluated through analysis of blood samples from pups by IFAT and MAT; bioassay - which consisted of inoculating Swiss mice with a pool of brain, lung, liver, striated skeletal muscle, tongue and diaphragm tissue samples from each litter - and by individual PCR of each of these tissue fragments. Additionally, the same types of tissue analyzed in the dams, including mammary, were collected from the offspring and individually subjected to PCR.

The pool of organs from each litter was divided into two parts: the first was digested in pepsin acid solution, according to Dubey (16), and the second was processed in natura. Both samples (digested and in natura) were subcutaneously inoculated into three Swiss mice, aged 30 days, which were observed for a 60-day period. Then, serology was performed by IFAT and MAT or, in case of death, peritoneal fluid was collected to verify the presence of tachyzoites.

DNA from milk and tissue samples was extracted by the scalable method using GFX® Genomic Blood DNA Purification kit (GE Healthcare/Life Sciences, USA) and purified with Illustra ${ }^{\circledR}$ Blood GenomicPrep Mini Spin kit (GE Healthcare/Life Sciences, USA). To verify the sensitivity of the assay, the detection threshold was determined in each tissue, by detecting variable concentrations of tachyzoites according to the milk and studied tissue. To identify T. gondii DNA in the samples, PCR was carried out by the B1 gene detection protocol of Homan et al. (17), and products were visualized through horizontal electrophoresis in $2 \%$ agar gel.

The GFX® Genomic Blood DNA Purification kit (GE Healthcare/Life Sciences, USA) permitted the detection of up to $1.5 \times 10^{1}$ tachyzoites $/ \mathrm{mL}$ in pure suspension of peritoneal exudate and $1.5 \times 10^{2}$ tachyzoites $/ \mathrm{mL}$ in milk samples contaminated with exudate. Also, the Illustra ${ }^{\circledR}$ Blood GenomicPrep Mini Spin Purification kit (GE Healthcare/Life Sciences, USA) allowed the detection of up to $1.5 \times 10^{1}$ tachyzoites $/ \mathrm{mL}$ in pure exudate rich in tachyzoites and brain suspension samples; $1.5 \times 10^{2}$ tachyzoites/mL in lung, tongue and diaphragm samples; and $1.5 \times 10^{3}$ tachyzoites/mL in liver, heart, striated skeletal muscle and mammary gland samples of female rats.

For each extraction sequence and milk and tissue sample analysis through PCR, positive and negative controls were used. Positive controls comprised milk samples 
from rats infected with $T$. gondii at the concentration of $2.0 \times 10^{2}$ tachyzoites $/ \mathrm{mL}$ and tissue samples at the concentrations of $2.0 \times 10^{2}$ (brain, lung and tongue suspensions) and $2.0 \times 10^{3}$ tachyzoites $/ \mathrm{mL}$ (heart, striated skeletal muscle, liver, diaphragm and mammary gland samples). Ultrapure water was used as negative control.

Litters were reduced to six pups per dam and the remaining young animals were euthanized after 21 days, together with their mothers. A chamber saturated with isoflurane vapor was used for euthanasia (18). Ketamine hydrochloride (25 $\mathrm{mg} / \mathrm{kg} /$ day) was intramuscularly injected to anesthetize the animals for blood and milk collection.

Three milk samples were PCR-positive, two on the $1^{\text {st }}$ and $5^{\text {th }}$ collection days from rat 1 , of $\mathrm{G} 1$, and one on the $1^{\text {st }}$ day post-infection from rat 3 of $\mathrm{G} 3$. Serology of litters from all G1 rats indicated seroconversion; however, bioassays were negative. In G3, four pups of dam 3 seroconverted and tested positive by bioassay tests (mice inoculated with a pool of their tissues). Two pups of rat 3 and 4 also presented positive results in bioassay tests (Table 1).

Table 1. Distribution of positive and negative pups according to the diagnostic technique and experimental group

\begin{tabular}{|c|c|c|c|c|c|c|c|c|c|c|c|c|}
\hline & \multicolumn{3}{|c|}{ Serological MAT } & \multicolumn{3}{|c|}{ Serological IFAT } & \multicolumn{3}{|c|}{ Bioassay } & \multicolumn{3}{|c|}{ PCR } \\
\hline & \multicolumn{3}{|c|}{ Group } & \multicolumn{3}{|c|}{ Group } & \multicolumn{3}{|c|}{ Group } & \multicolumn{3}{|c|}{ Group } \\
\hline & G1 & G3 & Total & G1 & G3 & Total & G1 & G3 & Total & G1 & G3 & Total \\
\hline Positive pups & 36 & 4 & 40 & 29 & 3 & 32 & 0 & 2 & 2 & 3 & 0 & 3 \\
\hline Negative pups & 0 & 32 & 32 & 7 & 33 & 40 & 36 & $24^{*}$ & 60 & 33 & 36 & 69 \\
\hline Total & 36 & 36 & 72 & 36 & 36 & 72 & 36 & 26 & 62 & 36 & 36 & 72 \\
\hline
\end{tabular}

${ }^{\star}$ Ten inoculated mice died

In G2, three dams and all litters died. The median survival was 13 days for adult rats and nine days for their offspring. Frequently observed clinical alterations included prostration and the loss of fur and weight. The peritoneal exudates from rats that died did not have tachyzoites. In this this group, serology, bioassay and PCR could not be performed in neonates.

Drugs are easily excreted through breast milk during the first days of lactation (17). It is believed that death of newborns may be due to high concentration of drugs in milk and their low capacity to biotransform them. Similarly, the immaturity of the immune 
system and the prolonged dexamethasone effects on the hypothalamic-pituitaryadrenal axis, resulting in reductions of antibody production and immunity, may have also contributed to early death of dams and their pups $(19,20)$.

Among the sample sources, only skeletal muscle from inoculated rats, of all three groups, presented T. gondii DNA, with $66.66 \%$ positivity. By PCR, pup 3 from dam 1 of $\mathrm{G} 1$ had positive liver and skeletal muscle samples, and pup 5 showed positivity only in the liver. In this same group, dam 2 had a pup that presented positive lung samples.

This study demonstrated that $T$. gondii was found in the milk of experimentally infected rats, both in chronic and acute infections, which is similar to the findings of Powell et al. (21). These authors also identified by PCR T. gondii DNA in the milk of cats experimentally infected at different gestational stages with cysts. In the present study, the milk presented intermittent parasite elimination, corroborating the results of Pettersen (7). Ruchman and Fowler (22) detected the parasite in the blood of rats intraperitoneally inoculated with tachyzoites of an $\mathrm{RH}$ strain from four hours to 16 days after inoculation. Bonametti et al. (23) reported a case of $T$. gondii transmission by a mother who had contracted primo-infection by ingesting raw goat meat with cysts and possibly transmitted the parasite to the newborn through breastfeeding. In the present study, Toxoplasma gondii was detected in the milk of experimentally infected Wistar female rats. Those are important factors that require further studies for clinical evaluation in children, since this disease tend to be highly severe in this age group, which may represent a public health problem when mothers are infected after birth.

\section{ACKNOWLEDGEMENTS}

We thank Fábio Hiroto Shimabukuro, Priscila Barbante, Rodrigo da Costa Silva and Aristeu Vieira da Silva for their collaboration; FAPESP for scholarships and research grants (processes 2005/03017-5 and 2006/02860-3); and CNPq for research grant (process 471.914/2006-1) and the scholarships of Felipe Gazza Romão and Taticia Ykeda. 


\section{REFERENCES}

1. Acha PN, Szyfres B, editors. Zoonoses and communicable diseases common to man and animals. $3^{\text {rd }}$ ed. Washington: Pan American Health Organization; 2003. 416 p.

2. Saari M, Räisänen S. Transmission of acute Toxoplasma infection. The survival of trophozoites in human tears, saliva, and urine and in cow's milk. Acta Ophthalmol (Copenh).1974;52(6):847-52.

3. Sogandares-Bernal F, Marchiondo AA, Duszynki DW, Ward JK. Prevalence of Toxoplasma antibodies in range vs. dairy cattle from the Bitterroot Valley of Montana. J Parasitol. 1975;61(5):965-6.

4. Sanger VL, Cole CR. Toxoplasmosis. VI. Isolation of Toxoplasma from milk, placentas and newborn pigs of asymptomatic carrier sows. Am $\mathrm{J}$ Vet Res. 1955;16(61 Part 1):536-9.

5. Riemann HP, Meyer ME, Theis JH, Kelso G, Behymer DE. Toxoplasmosis in an infant fed unpasteurized goat milk. J Pediatr. 1975;87(4):573-6.

6. Tenter AM, Heckeroth AR, Weiss LM. Toxoplasma gondii: from animals to humans. Int J Parasitol. 2000;30(12-13):1217-58.

7. Pettersen EK. Transmission of toxoplasmosis via milk from lactating mice. Acta Pathol Microbiol Immunol Scand B. 1984;92(3):175-6.

8. Dubey JP. Comparative infectivity of Toxoplasma gondii bradyzoites in rats and mice. J Parasitol.1998a;84(6):1279-82.

9. Hutchison WM, Hay J, Lee WR, Siim JC. A study of cataract in murine congenital toxoplasmosis. Ann Trop Med Parasitol. 1982;76(1):53-70.

10. Sims TA, Hay J, Talbot IC. Host-parasite relationship in the brains in mice with congenital toxoplasmosis. J Pathol. 1988;156(3):255-61.

11. Gazzinelli R, Xu Y, Hieny S, Cheever A, Sher A. Simultaneous depletion of CD4+ and CD8+ T lymphocytes is required to reactive chronic infection with Toxoplasma gondii. J Immunol. 1992;149(1):175-80.

12. Camargo ME. Introdução às técnicas de imunofluorescência. Rev Bras Patol Clin. 1974;10(3):143-71.

13. Desmonts G, Remington JS. Direct agglutination test for diagnosis of Toxoplasma infection: method for increasing sensitivity and specificity. J Clin Microbiol. 1980;11(6):562-8. 
14. Djurkovic-Djakovic O, Milenkovic $\mathrm{V}$. Murine model of drug-induced reactivation of Toxoplasma gondii. Acta Protozool. 2001;40(1):99-106.

15. Leite MS, Azeredo VB, Carmo MGT, Boaventura GT. Utilização da multimistura durante a lactação e seus efeitos na produção e composição do leite materno de ratas. Rev Nutr. 2002;15(2):211-21.

16. Dubey JP. Refinement of pepsin digestion method for isolation of Toxoplasma gondii from infected tissues. Vet Parasitol. 1998;74(1):75-7.

17. Homan WL, Vercammen M, De Braekeleer J, Verschueren H. Identification of a 200- to 300-fold repetitive 529 bp DNA fragment in Toxoplasma gondii, and its use for diagnostic and quantitative PCR. Int J Parasitol. 2000;30(1):69-75.

18. Brasil, Ministério da Saúde. Curso de Manipulação de Animais de Laboratório. Salvador: Fundação Oswaldo Cruz-Centro de Pesquisas Gonçalo Moniz; 2005. 84 p. 19. Bernardi MM. Exposição aos medicamentos durante o período perinatal. In: Spinosa HS, Górniak LS, Bernardi MM, editors. Farmacologia aplicada à medicina veterinária. $3^{\text {rd }}$ ed. Rio de Janeiro: Guanabara Koogan; 2002. p. 691-9.

20. Andrade MMJ. Antiiflamatórios esteroidais. In: Spinosa HS, Górniak LS, Bernardi $\mathrm{MM}$, editors. Farmacologia aplicada à medicina veterinária. $3^{\text {rd }}$ ed. Rio de Janeiro: Guanabara Koogan; 2002. p. 242-50.

21. Powell CC, Brewer M, Lappin MR. Detection of Toxoplasma gondii in the milk of experimentally infected lactating cats. Vet Parasitol. 2001;102(1-2):29-33.

22. Ruchman I, Fowler JC. Localization and persistence of Toxoplasma in tissues of experimentally infected white rats. Proc Soc Exp Biol Med. 1951;76(4):793-6.

23. Bonametti AM, Passos JN, Koga Da Silva EM, Macedo ZS. Probable transmission of acute toxoplasmosis through breast feeding. J Trop Pediatr. $1997 ; 43(2): 116$. 